INTERNATIONAL JOURNAL OF MULTidisciplinARY RESEARCH AND ANALYSis

ISSN(print): 2643-9840, ISSN(online): 2643-9875

Volume 05 Issue 01 January 2022

DOI: 10.47191/ijmra/v5-i1-22, Impact Factor: 6.072

Page No.- 171-184

\title{
Moderating Effect of Audit Committee Financial Expertise on Relationship between Monitoring Attributes and Audit Quality of Listed Oil and Gas Companies in Nigeria
}

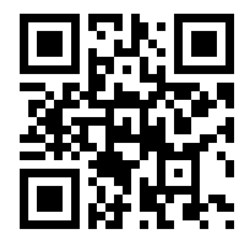

\author{
Mbatuegwu, Christopher David MSC, M.Ed., PhD. ${ }^{1}$, Musa. Ahmed Mohammed FCNA, PhD², \\ Yoko, Emmanuel Victor ${ }^{3}$ \\ ${ }^{1,3}$ Nigerian College of Accountancy Kwall, Plateau State \\ ${ }^{2}$ Association of National Accountant of Nigeria (ANAN), Abuja, Nigeria
}

ABSTRACT: Audit committee financial expertise, audit report quality, financial reporting accuracy, and corporate governance are under increased scrutiny. The audit committee, which is responsible for credible financial reporting, can play a significant role in overseeing the audit process. The study covered the period of 215-2919, and the population consisted of ten listed oil and gas companies on the Nigerian Stock Exchange (NSE). Since Afroil PIc was delisted in 2009, it was excluded from the study population. Data was extracted from the companies' published annual reports and accounts, which was analysed with the aid of Stata 13 version in order to obtain a result. Financial literacy appears to be more effective in diversified firms and in firms with mandatorily established audit committees. Independent directors serve a governance role that improves financial reporting quality, audit quality, and earnings quality. The study found that the audit committee's interaction with the audit committee has a strong statistical influence on the association between audit quality and non-executive directors.

\section{INTRODUCTION}

Corporate scandals at the turn of the century, as well as the 2008 financial crisis, are the most recent events to pique worldwide interest in audit report quality, financial reporting accuracy, and corporate governance. As a result, the public has been paying close attention to the truth and openness of reported financial accounting figures. The magnitude of the problem has also created expectations of further regulation in the economy, which has had a significant influence on reporting, auditing, and governance. As a result, financial analysts, regulators, and investors have become more worried about the integrity of financial reporting, with audit quality serving as a key indicator.

The efficiency of corporate governance aligns managers' and owners' interests in one direction (Fama \& Jensen, 1983). In light of the monitoring process, several other control mechanisms, notably shareholder compositions and audit committees, are adopted to assure the authenticity of financial reporting. These consist of the names of independent directors and non-executive directors, as well as the nature and identity of equity owners.

The roles of the audit committee include overseeing the financial reporting process and monitoring management because management intends to manipulate figures for their own interests. Accordingly, external auditors play the role of giving independent opinions on the financial statements of firms if the financial statements are prepared with due care to avoid any material bias or misstatements. Hence, the audit committee and external auditors play a significant role in ascertaining the validity, acceptability, and reliability of financial statements (Mbatuegwu \& Musa, 2021).

Mbatuegwu, Aza, and Uwaleke (2019) asserted that the audit committee, which is responsible for credible financial reporting, can play a significant role in overseeing the audit process and helping to mediate disputes between the board and the auditor. The Blue-Ribbon Panel (1998) concerned audit committee knowledge and financial expertise as it could affect their effectiveness. The panel states that members of the audit committee should be financial experts. As a result, it can affect the monitoring process and possible financial fraud. Financial literacy appears to be more effective in diversified firms and firms with mandatorily established audit committees (Yoon, 2012).

Gao, Omar, and Shelley (2019) posit that companies with vibrant independent directors serving on the audit committee have higher financial reporting quality, more efficient audits, and higher earnings quality. This suggests that lead independent directors 


\section{Moderating Effect of Audit Committee Financial Expertise on Relationship between Monitoring Attributes and Audit Quality of Listed Oil and Gas Companies in Nigeria}

on audit committees serve a governance role that improves financial reporting quality, audit quality, and earnings quality. Independent directors are also audit committee members and create direct connections between audit committees, external audit firms, and companies' CEOs.

This study seeks to moderate the effect of audit committee financial expertise on the relationship between monitoring attributes and audit quality of listed oil and gas companies in Nigeria.

The need to ensure a sound monitoring system for corporate organizations cannot be overemphasized. This is based on the fact that an effective monitoring system is essential to improving the quality of financial reporting, which, in turn, has an impact on the confidence of investors.

In Nigeria, the oil and gas sector are pivotal to economic progress since the bulk of the government's revenue is generated from this sector. It is expected that this sector should receive the most attention in terms of monitoring and supervision, given its economic importance. However, the reverse is the case. Premium times Nigeria (2013) reported that Trafigura and Vitol are oil and gas companies suspected to be involved in siphoning $\$ 6.8$ billion of crude oil revenues. Also, the cases of Willbros Group Inc., ABB Vetco Gray, Trafigura, and Vitol. According to the Department of Justice (2004) and (2008), ABB Vetco Gray and Willbros Group Inc. is a US company with a UK subsidiary in Nigeria that admitted to making corrupt payments to officials of oil and gas companies and its subsidiary NAPIMS to the tune of $\$ 1$ million and $\$ 6.3$ million to favour them in bidding and recommendation. According to Sanusi (2013), oil and gas companies have not remitted over $\$ 49.8$ billion in proceeds from crude oil to the federal government. According to Vanguard (2017) and Premium Time (2018), the director of Ontario Oil and Gas Limited was convicted for 10 years for defrauding the Federal Government of Nigeria of the sum of N754 million with respect to oil and gas subsidy fraud that existed between 2012 and 2014. Not to mention the recent case of Oando Plc (2018), where the director of the company was found guilty of fraudulent financial reporting and was relieved from operating as the CEO of the company.

Consequently, to fill the existing gap in the literature, first, some of these studies were carried out in foreign economies, which, given the differences in economic variables, cannot be applied to the Nigerian situation for policy and decision-making because of the problem of external validity. Also, even the Nigerian studies were carried out in other sectors (Adeyemi \& Temitope, 2010; Mgbame and Onoyase, 2015; Ndubuisi and Ezechukwu, 2017; Ebimobowei, 2013), and as such, their findings cannot be applied to the oil and gas sector given the differences in the nature and operations of such companies (Sectorial Peculiarities). Again, this study combines variables of both boards of directors and ownership structure (non-executive directors, ownership concentration, and audit committee) to constitute the monitoring attributes, which, to the best of the researchers' knowledge, have not been applied by previous studies. The timing gap will also be filled as this study uses data from the 10 listed oil and gas companies from 2017 to 2020.

Furthermore, the measurement of audit quality has been done using audit firm size for most of the previous studies. This study introduces other measures of audit quality, such as audit tenure and auditors' industry specialization, to ascertain the effect of each of the monitoring attributes on these individual measurements.

The study also interacts with the effect of audit committee financial expertise with monitoring attributes to ascertain their effects on audit quality. Given the problems articulated and the gaps existing in the literature, this study seeks to examine the moderating effect of audit committee financial expertise on the relationship between monitoring attributes and audit quality of quoted oil and gas companies in Nigeria.

1. What is the moderating effect of the audit committee's financial expertise on the relationship between non-executive directors and the audit quality of listed oil and gas companies in Nigeria?

2. What is the moderating effect of the audit committee's financial expertise on the relationship between ownership concentration and audit quality of listed oil and gas companies in Nigeria?

The broad objective of this study is to examine the effect of monitoring attributes on the audit quality of listed oil and gas companies in Nigeria. Specifically, the study aims to

1. identify the moderating effect of the audit committee's financial expertise on the relationship between non-executive directors and the audit quality of listed oil and gas companies in Nigeria.

2. Determine the moderating effect of the audit committee's financial expertise on the relationship between ownership concentration and audit quality of listed oil and gas companies in Nigeria.

The following hypotheses will guide the study:

$H_{01}$ : Audit committee financial expertise does not significantly moderate the relationship between non-executive directors and the audit quality of listed oil and gas companies in Nigeria. 


\section{Moderating Effect of Audit Committee Financial Expertise on Relationship between Monitoring Attributes and Audit Quality of Listed Oil and Gas Companies in Nigeria}

Hos: Audit committee financial expertise does not significantly moderate the relationship between ownership concentration and audit quality of listed oil and gas companies in Nigeria.

\section{Audit Committee Financial Expertise}

Researchers have defined audit committees in a variety of ways. According to Cadbury (1992), the audit committee is a formal institution used by corporate owners to discipline organizations. Morrin and Jarrell (2001) argued that an audit committee is a special group of experts that controls and safeguards the interests of capital market investors, corporate owners, managers, employees, suppliers, and creditors.

An audit committee is not only a group of people but also a set of processes, policies, laws, and institutions affecting the way a corporation is directed, administrated, or controlled. A perfect audit committee can strengthen intra-company control, reduce opportunistic behaviours and lower the asymmetry of information, so it has a positive impact on the high quality of disclosed information (Li \& Qi, 2008).

The audit committee, thus, is considered to be an additional internal governance mechanism whose impact is to improve the quality of financial management of a company and enhance its performance. In this respect, an audit committee has four main characteristics that should be considered: audit committee independence, audit committee size, audit committee diversity, and audit committee meetings.

The Nortel failure illustrates the consequences of ineffective audit committees, where independent directors lacked understanding of due diligence and yet the audit committee failed in its duties to oversee the internal and external audit processes (Thain, 2004). Based on the literature, it would seem that the audit committee serves primarily to reduce agency costs and thereby improve the net performance of the firm.

\section{The Concept of Audit Quality}

There are many attempts to define the concept of audit quality either at the professional organization level or at the academic level. At the professional organization level, for example, the International Federation of Accountants (IFAC, 2009: 12) pointed to the concept of auditing quality in the international standard on quality control. It stated that "the objective of the audit firm is to establish and maintain a system of quality control to provide it with reasonable assurance that:

(a) the firm and its employees adhere to professional standards as well as applicable legal and regulatory requirements; and

(b) Reports issued by the firm or engagement partners are appropriate in the circumstances "(IFAC, 2009; 15). This means that the concept of quality from the perspective of IFAC lies in compliance with professional standards and legal and regulatory requirements.

In the same context, the International Auditing and Assurance Standards Board (IAASB, 2010) in its framework for audit quality mentioned that the purpose of an audit is to enhance the degree of confidence of intended users in the financial statements. This can be achieved through gathering sufficient appropriate audit evidence to express an opinion on whether the financial statements are prepared, in all material respects, by the applicable financial reporting framework. This indicates that the IAASB found a link between auditing quality and audit evidence that is used to express an opinion about firms' financial statements according to financial reporting standards.

ICAEW (2002) suggested a definition for audit quality by stating that, at its heart, audit quality is about delivering an appropriate professional opinion supported by the necessary evidence and objective judgments. As long as the auditors provide an independent audit opinion that is supported by adequate audit evidence, the regulator assumes that such auditors have performed a quality auditing service.

Also, Deis and Giroux (2002) argued that auditing quality is the auditor's ability to detect weaknesses and gaps in the accounting system for the client and the reporting. However, Copley and Doucet (2013) went in another direction by defining auditing quality as the application of professional standards related to fieldwork and reporting standards.

The importance of audit quality lies in the reduction and mitigation of agency conflicts, providing confidence and credibility in financial statements that have been audited. "Audit quality" is a set of methods and techniques that work to reduce errors and fraud. The probability of detection is a matter of competence, whereas the probability of revelation depends on the independence of the auditor. (Abu ljela \& Hamdan, 2010, Piot \& Janin, 2005).

\section{Measures of Audit Quality}

Although several studies have sought to measure "actual" audit quality, what has prevailed in the literature, since DeAngelo's study (1981), are the metrics that try to capture "perceived" audit quality, such as (i) the auditor's size, particularly big-4, as in DeAngelo (1981), Ilaboya and Ohiokha (2013), Dang (2004), Gu, Lee and Rosett (2005), Behn, Choi and Kang (2008), Kanagaretnam, 


\section{Moderating Effect of Audit Committee Financial Expertise on Relationship between Monitoring Attributes and Audit Quality of Listed Oil and Gas Companies in Nigeria}

Krishnan and Lobo (2010), and Zagonov (2011); (ii) auditor specialization, as in Behn et al. (2008), Chambers and Payne (2008), Romanus, Maher, and Fleming (2008) and Kanagaretnam, Krishnan et al. (2009, 2010); (iii) auditor issuing going concern opinion as in Teoh and Wong (1993) and Ghosh and Moon (2010); and (iv) accrual models as in Dang (2004) and Behn et al. (2008). For this study, audit firm size is used as a measure of audit quality.

Summing up, DeAngelo (1981); Palmrose (1988); Deis and Giroux (1992); Becker et al. (1998); Francis and Krishnan, (1999); Krishnan and Schauer (2000); Kim, Chung, and Firth, (2003) and Krishnan, (2003) agree on audit quality as a function of audit firm size and demonstrate that larger (Big 8, Big 6, Big 5 or Big 4) audit firms possess a greater capacity to measure audit quality. Wooten (2003) found that detecting material misstatements is influenced by how well the audit team performs the audit, which in turn is influenced by the quality control system and management resources of the audit firm.

\section{The Concept of Monitoring Attributes}

Monitoring is the steady reflection and recording of activities that might take place in an organization. Monitoring involves the process of tracking, reviewing, and regulating the development of plans and goals described in the administration plan (Farber \& David, 2005). In addition, monitoring consists of status reporting, development size, and outcome estimation (Guide, 2001). In early 1967, the whole idea of monitoring attributes received great attention, although the expected functions of this committee were uncertain. The American Institute of Certified Public Accountants (AICPA) (1967) made some recommendations that audit committee boards be established so that external auditors can communicate and interact with the audit committee in respect to the organizational goals and objectives, which are materialistic in respect of audit or verification and classification to produce audit quality (Enofe, Aronmwan \& Abadua, 2013). Furthermore, according to Onofe et al. (2013), the Security and Exchange Commission (SEC) issued accounting series No123 in 1972, requiring standing audit committees to be composed of outside directors.

Furthermore, apart from the Companies and Allied Matters Act (2004) as amended, which provides for the establishment of the audit committee (which is one of the numerous mechanisms for monitoring corporate organizations), in the work of Lindsell (1992), monitoring attributes are part and parcel of the audit committee mechanism in checking the quality, credibility, and objectivity of financial reporting because it forms part of accounting and audit oversight functions.

A company is an economic body in which the owner is expected to be separated from those that manage the business. Failure stands for the incapability of a concern to achieve its primary arm and objective, which is "profit-making" in the long run. On the other hand, failure is a term used interchangeably with pain, illiquidity, bankruptcy, unrelenting loss, liquidation, and winding up.

\section{Executive Directors}

According to the Australian Institute of Company Directors (2001), a non-executive director is not employed by the organization. This is not the same as an independent director who is not only not employed by the organization (non-executive director) but also has no relations with the organization other than being a director of the firm. Non-executive directors can additionally be referred to as' part-time ',' independent ', or 'external directors', taking all the essential actions as advisers to management and making certain that the enterprise is run in the nice pastimes of the shareholders (Houston \& Lewis, 1992; Kakabadse \& Kakabadse, 2007; David, Uwaleke \& Azah 2020).

According to the Institute of Directors (2010), a non-executive director (which can be abbreviated as NED, non-exec, or NXD), or external director, is a member of the board of directors of a company or firm who does not fully participate or does not form part of the executive management team of the organization. Because they are not employed by the company or any of its associated ways, they are different from inside directors, who are members of the board who have served the organization or who have previously served as decision-making managers of the company or organization. (Mbatuegwu \& Musa, 2021)

Directors that are more experienced, have specialist skills, and better networks are usually paid more by the marketplace. Zakaria (2012) required that one-third or two members, whichever is higher, of the total number of directors be independent. It also shows that directors with greater independence are often not rewarded.

Non-executive directors are outside directors who are independent of the company. They are also called "independent directors" because they have neither personal nor business relationships with the company (Ogbechie \& Koufopoulos, 2010). A non-exec is any director who is not a representative or member of the immediate family of a shareholder and who has had no business relationship with the firm for the past three years or more.

Non-executive directors provide superior benefits to the company due to their independence from the management of the organization. This single act of independence attracted investors to invest more in the organizations as it helps them make better investment decisions. Furthermore, the presence of non-executives is generally believed to have provided better governance, effective monitoring, and quality. 


\section{Moderating Effect of Audit Committee Financial Expertise on Relationship between Monitoring Attributes and Audit Quality of Listed Oil and Gas Companies in Nigeria}

\section{Ownership Concentration}

Ownership concentration refers to the amount of time spent on the existence of large block holders in a firm (Thomsen \& Pedersan, 2000). Usually, a stockholder who holds $5 \%$ or more of the company's equity is reflected as a major stockholder. The shareholding of an owner should be significant enough to provide for monitoring the actions of the management. The major shareholder can be an individual, a domestic or foreign corporation, an institutional investor, or the state.

Ownership concentration refers to the spread of the shares owned by a certain number of individuals or institutions; ownership mix, on the other hand, is related to certain institutions or groups such as governments, private companies, or foreign partners among the shareholders (Claessens \& Djankov, 1998).

The role of ownership structure in the setting of concentrated ownership is to assess the cash flow contents with regard to the block holder's role in the perspective of diffused ownership. The accounting literature contains extensive research on how the agency problem between owners and managers affects earnings quality as well as the quality of accounting information of firms.

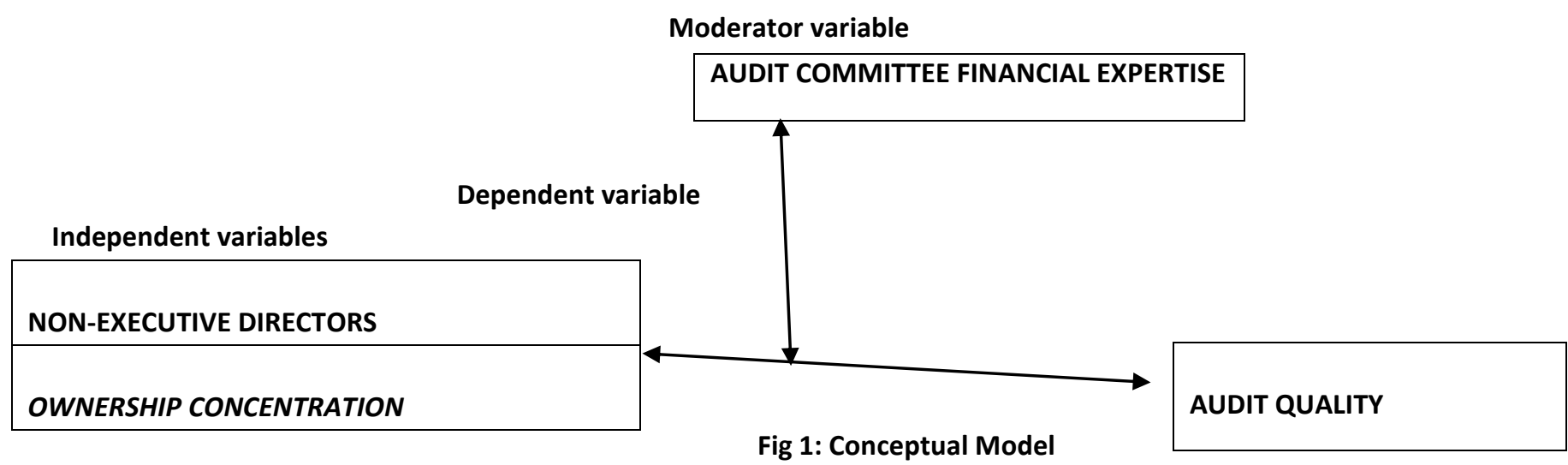

The audit committee's financial expertise, being the moderator, intervened in the relationship between the independent variables (non-executive directors and ownership concentration) and the dependent variables (audit quality) of oil and gas companies in Nigeria.

\section{EMPIRICAL REVIEW}

\section{Audit Committee Financial Expertise and Audit Quality}

Ojeka, Fakile, lyoha, Adegboye, and Olokoyo (2019) examined the impact of audit committee objectivity (contingent on CEO power) on the quality of financial reporting in the Nigerian banking sector. The study adopted a survey research approach and secondary data was extracted from the financial statement. The OLS and LSDV analyses were used to investigate the impact of audit committee objectivity on the quality of financial reporting with or without CEO power and influence. The findings showed that while audit committee independence impacts positively on the relevance and reliability of the financial report, the same cannot be said when there is CEO power. CEO power in the audit committee mitigated the benefits of independence and caused its overall effects on financial reporting quality to be of no significance in terms of relevance and reliability. This study adopted a survey research approach, while this current study will adopt a descriptive approach, extracting secondary data from annual reports of oil and gas companies from 2009 to 2018.

Khudhari, Al-Zubadi, and Ali (2018) explored the impact of internal and external governance mechanisms such as board size, audit committee independence, audit committee expertise, and audit committee meetings on the quality of audits in selected firms. The study was carried out on a sample of Iraqi non-financial firms. The dependent variable is the audit quality, measured as a dummy variable, and it receives 1 if a firm receives audit services from one of the big four auditing firms and zero otherwise. To achieve the research objectives, the study uses a logit regression technique. The results indicate that there was a positive relationship between audit quality and the percentage of non-executive directors in the audit committee.

This study, although employing the use of Big4 to measure audit quality like the current study, was done in a foreign country with a difference in economic variables, which accounts for the measure difference in this study.

Asiriuwa, Aronmwan, Uwuigbe, and Uwuigbe (2018) examined audit committee attributes and audit quality with emphasis on the specific requirements of the 2011 SEC code. The study applied the deductive approach via the ex post facto research design and the binary probit regression model in analyzing the various hypotheses put forward in the study. The data used for the study was gathered for 150 firm-year observations from the annual reports of quoted companies on the floor of the Nigerian Stock Exchange. 


\section{Moderating Effect of Audit Committee Financial Expertise on Relationship between Monitoring Attributes and Audit Quality of Listed Oil and Gas Companies in Nigeria}

Findings from the study revealed that audit committee size, frequency of meetings, number of experts, and overall effectiveness all have a positive relationship with audit quality. However, only size and overall effectiveness were significant in their relationship. Audit committees possessing greater levels of financial expertise are associated with higher audit fees. Ghafran and O'Sullivan (2017) investigate the impact of audit committee expertise on one measure of audit quality: audit fees paid by FTSE350 companies. Their findings highlight the usefulness of segregating financial expertise between specialists and non-specialists, something which regulators in the UK and the USA currently do not do. This study was carried out by the two economic powers in the world, which, given the level of our economy, their outcome cannot be used to make decisions.

The results show that audit committee expertise and meetings have positive and non-significant effects on the audit quality of listed consumer goods companies in Nigeria. This study is similar to the current study concerning this particular variable since it measured audit quality using the size and also used multiple regression as a statistical technique. However, the study of sectorial peculiarities calls for a major difference in the world.

\section{Non-executive Directors and Audit Quality}

Shukla, Narayanasamy, Ayyalusamy, and Pandya, (2020). Observational research explores the impact of independent directors (non-executive directors) on the business risks of Indian banks. The paper is based on data collected over seven years (2009-2016) for a set of 29 Indian banks making up the National Stock Exchange 500 Series. Data on the independent directors of the sampled banks is extracted from the bank's annual reports, while data on the contingent and control variables is obtained from the Ace Equity and Reserve Bank of India databases. The research uses a panel data methodology to analyze the data generated by the sample banks. The study concludes that independent directors are increasing business risks for Indian banks (measured through equity beta). This study is similar to the current study concerning this particular variable because it measured the consistency of the audit using its size and also used multiple regression as a statistical technique. However, the analysis of the sector's peculiarities calls for a significant difference throughout the world.

Akhidime (2015) examined the impact of the board structure of Nigerian banks on the audit quality. The study is based on the published audited accounts of 19 banks that were selected by simple random sampling technique from the population of the 25 Nigerian banks over the post-consolidation/reform period of five years. The variables of the study were analysed using binary logistic regression analysis. The hypotheses of the study were tested using F-ratios. From the results of the pooled binary regression of the pooled data at a $5 \%$ level of significance, Results of the study confirm that non-executive directors positively impact the banks' audit quality. This study was on Nigerian banks and used logit regression as a statistical technique for data analysis, while this current study will be on oil and gas companies and will employ multiple regression analysis as a technique for data analysis, giving us the problem of sectoral peculiarity and differences in statistical techniques for analysis.

Adelopo (2010) ascertained the effect of non-executive directors on audit quality in non-banking institutions. The study covered a period between 2002 and 2008. NED was measured using the proportion of non-executive directors on the board, and audit quality was measured using total fees paid to auditors. The study used regression analysis as a statistical tool. The result indicated that the higher the number of independent non-executive directors there are on the board, the higher the total fees (both audit and non-audit) that are earned by the auditor from their client. The result suggests that rather than reducing the value of services purchased from the external auditors, non-executive directors will signal preferences for auditing and reporting quality and auditing coverage by buying more services from the auditors to signal transparency to the market and boost market confidence in the reports of the firm. Although this study was done in Nigeria, the data for the study was collected up to 2008, and given the trend of occurrences in the Nigerian economy from 2008 to date, the result of the study cannot be used to make an informed business decision on current issues concerning board structure and audit quality.

Adeyemi and Fagbemi's (2010) study provided evidence on corporate governance, audit quality, and firm-related attributes from a developing country, Nigeria. Logistic regression was used in investigating the questions that were raised in the study. Findings from the study show that ownership by the non-executive director has the possibility of increasing the quality of auditing. Evidence also exists that the size of the company and business leverage are important factors in audit quality for companies quoted on the Nigerian Stock Exchange. The study suggests that the composition of non-executive directors as members of the board should be sustained and improved upon to enhance audit quality. The findings of the previous study cannot be used to make informed decisions in the oil and gas sector based on sectoral peculiarities.

\section{Concentration of ownership and audit quality}

Murtaza, Noor, Aguir, and Batool (2020) research on the role of ownership concentration and dividend policy in the firm production of Pakistani chemical industry firms. The research used secondary data from the annual reports of the companies listed on the Karachi Stock Exchange (KSE). Nevertheless, the criteria for inclusion of the 26 publicly traded companies are from 2012 to 


\section{Moderating Effect of Audit Committee Financial Expertise on Relationship between Monitoring Attributes and Audit Quality of Listed Oil and Gas Companies in Nigeria}

2017. The study was based on the Least Squares Generalized Model. The findings show that the concentration of ownership has a clear positive association with the financial performance of the company. This argues that larger shareholders should attribute the alignment of management incentives to shareholder interests. They're also monitoring the team very precisely and effectively. The dividend strategy has a good relationship with ROA. Leverage and tangibility have a strong negative relationship with firm performance. The study was performed abroad and was not at the critical time of COVID-19. Also, it cannot be used to make decisions in the oil and gas sector based on sectoral peculiarities.

Nam, Chi, and David (2020) investigate corporate governance connections with firm risk-taking and results in a traditional border equity market marked by a high concentration of ownership and poor investor security. Using a wide sample of Vietnamese listed companies and finding no association between the concentration of ownership and the profitability of the company, There is a non-linear relationship between the concentration of ownership and the value of the firm, and concentrated ownership increases the risk of accounting success. However, there is no evidence of a correlation between the concentration and the risk of market performance. In the end, the results confirm the important discrepancies in the usage of the two output alternatives. The results of the previous study cannot be used to make more informed decisions in the oil and gas sector based on sectoral peculiarities. Alzeaideen and Al-Rawash (2018) examined the combined effect of ownership concentration, foreign ownership, and institutional ownership on the audit quality of listed companies on the Amman stock exchange. The sample of the study consisted of 132 companies from 2005 to 2016. The analysis of logistic regression was used to investigate the relationship between the audit quality measured based on the audit firms' size as a dependent variable. The results provided evidence that foreign ownership, institutional ownership, and ownership concentration have a positive and statistically significant effect on audit quality. The current study differs significantly from the current study because it will be a combination of monitoring attributes and not restricted to only ownership structure as a surrogate for audit quality. Other variables such as board structure and audit committee effectiveness are included, which accounts for the significant difference. The current study will use multiple regression against the logit regression used in this study.

Rad, Salehi, and Pour (2016) assessed the effect of the interaction of audit quality and ownership structure on earnings management of listed firms on the Tehran Stock Exchange. The variables examined are auditor reputation, auditor tenure, ownership concentration, and institutional ownership as indicators of audit quality and ownership structure, respectively. Also, the absolute value of the discretionary accruals model of Modified Jones (1995) as a direct indicator of earnings management has been used. 100 firms from listed firms on the Tehran Stock Exchange for 5 years (2009-2013) have been tested. Multiple linear regression models with panel data and fixed effects are used. The results of the research hypotheses show that ownership concentration weakens the negative impact of auditor reputation and auditor tenure on earnings management. The measure of audit quality for the current study differs from the previous study as it will use audit firm size as a measure of auditing quality.

\section{THEORETICAL FRAMEWORK}

For the purpose of this study, theories such as agency theory and source dependency theory were succinctly discussed. However, agency theory provides a backdrop against which this study stands.

\section{Agency Theory}

An agency theory connection is defined as a contract under which one or more people (the principals) engage another person (the agent) to perform some service on their behalf that involves delegating some decision-making authority. Jensen and Meckling (1976) essentially describe the relationship between two parties: the owner as a principal and management as an agent. The theory states that the separation of ownership from control of modern-day businesses has turned the relationship between the owners (shareholders) and controllers (managers) into that of an agent and a principal.

More so, Fama and Jensen (1983). Shleifer and Vishny (1986) note that strong corporate governance within a firm would moderate the problem of information asymmetry and reduce agency costs through the alignment of interests between the managers and shareholders. The theory is relevant to this study because higher audit quality could be expected in firms with stronger corporate governance.

\section{Resource Dependence Theory:}

The resource-based theory of the firm, propounded by Wernerfelt (1984), is regarded as one of the theories of strategic management that is widely referenced, particularly because of its practical relevance to contemporary management practices. Resource dependence theory provides a theoretical foundation for the role of the board of directors as a resource to the firm (Johnson, 1996; Hillman \& Cannella, 2000). Penrose (1959) stressed the importance of unique bundles of resources and firm control that are crucial for its growth. 


\section{Moderating Effect of Audit Committee Financial Expertise on Relationship between Monitoring Attributes and Audit Quality of Listed Oil and Gas Companies in Nigeria}

The resource dependence theory contends that organizations attempt to exert control over their environment by co-opting the resources required to survive (Pfeffer \& Salancik, 1978). From this point of view, firm governance structures and board composition are viewed as resources that can add value to the firm. (Barney, 1991; Daft, 2006; Mbatuegwu, 2021).

\section{RESEARCH METHODOLOGY}

This study adopts a descriptive correlational research design to investigate the moderating effect of monitoring attributes on audit quality among listed oil and gas companies in Nigeria.

\section{Population of the Study}

Table 1

\begin{tabular}{|l|l|}
\hline S/N & Name of Company \\
\hline 1 & Forte Oil Plc \\
\hline 2 & MRS Oil Nigeria Plc \\
\hline 3 & Total Nigeria Plc \\
\hline 4 & Mobil Oil Nigeria Plc \\
\hline 5 & Conoil Plc \\
\hline 6 & Afroil Plc \\
\hline 7 & Oando Plc \\
\hline 8 & Eterna Oil \& Gas Plc \\
\hline 9 & Japaul Oil \& Maritime Services Plc \\
\hline 10 & Beco Petroleum Products Plc \\
\hline
\end{tabular}

As of December 2019, the population consists of 10 listed oil and gas companies on the Nigerian Stock Exchange (NSE) as of December 2019, though the number of companies was reduced to a working population of nine (9). Afroil Plc $(* *)$ was excluded from the study population because it was delisted in 2009 and had no published financial reports for the 2015-2019 period. Secondary data was extracted from the companies' published annual reports and accounts, as well as the NSE factbook, for the relevant years and analyzed using Stata 13 version.

Logit regression is used to examine the moderating effect of audit committee financial expertise on the relationship between monitoring attributes and audit quality of listed oil and gas firms in Nigeria. The model is for testing the hypothesized link between a non-executive director, ownership concentration, and auditing quality in quoted oil and gas companies in Nigeria.

Though employing a more comprehensive approach, the study builds on the previous models of Adeyemi and Fagbami (2010); Salleh et al. (2006); Abdullah (2008); Seyedah (2016); Glover-Akpey and Azembila (2016) with minor modifications to suit the particular purpose of the study. The model is presented below:

AQit $=\beta 0+\beta 1$ NEDit $+\beta 2 O C i t+\beta 5$ ACFEit $+\beta 6$ NEDit *ACFEit $+\beta 7$ OCit *ACFEit $+\beta 7$ ISit *ACFEit + $\beta 8$ IDit *ACFEit eit $\ldots .$. (i)

Where;

AQ stands for Audit Quality.

NED $=$ Non-Executive Directors

OC stands for Ownership Concentration.

ACFE= Audit Committee

$\beta 1-\beta 3=$ are the parameters estimated or coefficients in the equation.

$\beta 0=$ is the intercept

eit=error term 


\section{Moderating Effect of Audit Committee Financial Expertise on Relationship between Monitoring Attributes and Audit}

Quality of Listed Oil and Gas Companies in Nigeria

\section{MEASUREMENT OF VARIABLES}

\section{Dependent variable}

Many researchers measure the concept of audit quality by using different proxies of audit quality. For example, Manry et al. (2008) used an estimated discretionary accrual to measure audit quality, and Li and Lin (2005) used non-audit fees to examine audit quality.

For the current study, the dependent variable AQ will be measured using a proxy of Audit Quality Assessments (AQ) and coded as (1) or else 0. Also, in line with DeAngelo, 1981; Deis \& Giroux, 1992; Becker et al., 1998; Francis \& Krishnan, 1999; Krishnan \& Schauer, 2000; Krishnan, 2003; Okoli \& Izedonmi, 2014; Okoli, 2014; Ugwunta, Ugwuanyi \& Ngwa, 2018, Mbatuegwu 2021.

\section{Descriptive Statistics}

This section contains the description of the properties of the variables, ranging from the mean of each variable to the minimum, maximum, and standard deviation.

Table 2: Descriptive Statistics

\begin{tabular}{lllll}
\hline Variables & Mean & Std. Dev. & Min & Max \\
\hline AQ & .6777778 & .4699457 & 0 & 1 \\
AC*NED & .230867 & .095639 & .137648 & .412568 \\
AC*OC & .346754 & .146834 & .116754 & .643875 \\
\hline
\end{tabular}

Source: STATA OUTPUT 2021

Table 2. also showed that the moderating effect of the audit committee financial expertise on non-executive directors improved audit quality by $23 \%$. This means a mix of the audit committee and non-executive directors can improve the quality of audits of financial reports in oil and gas firms in Nigeria. The minimum contribution is $13 \%$ while the maximum is $41 \%$. The Table also indicated that the moderating influence of audit committee on ownership concentration and audit quality of oil and gas firms in Nigeria have an average of .34\% during the period of the study, from the mean of .346754 with a standard deviation of .146834 , and the minimum and maximum value of .116754 and .643875 respectively. The standard deviation suggests that the data is spread around the mean.

\section{Test for Normality}

An assessment of the normality of data is a prerequisite for many statistical observations because normal data is an underlying assumption in parametric testing. The Shapiro-Wilk $W$ test for normality is the most powerful in most situations.

Table 3: Normality Test

\begin{tabular}{lccccc}
\hline Variables & Obs & W & V & Z & p-values \\
\hline AC*NED & 90 & 0.874563 & 7.654 & 4.875 & 0.00004 \\
AC*OC & 90 & 0.86765 & 8.675 & 4.876 & 0.00000
\end{tabular}

Source: STATA Output, 2021.

From table 3 , it can be seen that the total number of observations was 90 , while the $W$ value stood at 0.874563 and 0.86765 for audit quality, the interaction between institutional ownership and independent directors, respectively. The result, as indicated, showed that the data for all variables is normally distributed. This is based on the submission that the test statistic $W$ may be written as the square of the Pearson correlation coefficient between the ordered observations and a set of weights which are used to calculate the numerator. Since these weights are asymptotically proportional to the corresponding expected normal order statistics, $W$ is roughly a measure of the straightness of the normal quantile-quantile plot. Hence, the closer $W$ is to one, the more normal the sample is. 


\section{Moderating Effect of Audit Committee Financial Expertise on Relationship between Monitoring Attributes and Audit Quality of Listed Oil and Gas Companies in Nigeria}

\section{Test for multicollinearity.}

The non-existence of multicollinearity is a key assumption of linear regression analysis. Multicollinearity occurs when the explanatory variables are not independent of each other. Multicollinearity is examined using tolerance and variance inflation factor (VIF) values. The result of the multicollinearity test is shown in the table below.

Table 4: Tolerance and VIF values

\begin{tabular}{lll}
\hline Variable & VIF & $1 /$ VIF \\
\hline AC*NED & 1.56 & 0.3426 \\
AC*OC & 1.48 & 0.4325 \\
Mean VIF I & 2.47 & \\
\hline
\end{tabular}

Source: STATA Output, 2021.

Based on the evidence presented in Table 4, it can be concluded that there is no Multicollinearity problem. This is because the VIF values for all the variables are less than 10 and the tolerance values for all the variables are greater than 0.10 (rule of thumb). Meanwhile, the goodness of fit test which is a statistical hypothesis test to show how sample data fit a distribution from a population with a normal distribution shows a Pearson chi2 value of 81.57 and a corresponding probability of 0.0044 . This indicated that the adjustment of the observations problems is well and no errors exist underlining the general fitness of the model.

\section{Regression Results}

The results of the logistics regression model are presented below as well as the test of the hypotheses.

Table 5: Logistic Regression Result

\begin{tabular}{lllll}
\hline AQ & Coefficient & $\mathrm{Z}$ & p-value & Remark \\
\hline NED & 5.688247 & 1.87 & 0.061 & Insignificant \\
OC & -.1014958 & -10.34 & 0.000 & Significant \\
AC*NED & 7.241269 & 2.22 & 0.027 & Significant \\
AC*OC & -4.135281 & -2.77 & 0.006 & Significant \\
R-Square & 0.4338 & & & \\
LR chi2(4) & 45.13 & & & \\
Prob. of chi2 & 0.0001 & & & \\
\hline
\end{tabular}

Source: STATA Output, 2021.

The R-square value showed the level at which the explanatory variables explain the dependent variable. Table 5 revealed that the R-square is 0.4338 . This implied that the monitoring variables in the study explained the audit quality (AQ) to the tune of $43 \%$. The value of $\mathrm{F}$ - statistic is 45.13 with a probability of chi2 $=0.0001$. The probability of chi 2 is significant at $1 \%$, indicating that the model is fit. This serves as substantial evidence to conclude that the monitoring attributes selected can be used to predict the dependent variable in the area covered by the study.

Audit committee financial expertise does not significantly moderate the relationship between non-executive directors and audit quality of listed oil and gas companies in Nigeria.

The result of the logistics regression shows that the moderating effect of audit committee financial expertise has a significant effect on the relationship between non-executive directors and audit quality of quoted oil and gas companies in Nigeria. This is 


\section{Moderating Effect of Audit Committee Financial Expertise on Relationship between Monitoring Attributes and Audit Quality of Listed Oil and Gas Companies in Nigeria}

evidenced by the $p$-value of 0.027 and coefficient of 7.241269 which evidences that the interaction of audit committee expertise has strong statistical influence on the association between audit quality in the area covered by the study. Based on this, the study rejects the null hypothesis which states audit committee financial expertise does not significantly moderate the relationship between non-executive directors and audit quality of listed oil and gas companies in Nigeria.

Audit committee financial expertise does not significantly moderate the relationship between ownership concentration and audit quality of listed oil and gas companies in Nigeria.

Again, the logistic regression shows that audit committee financial expertise as a moderator has a significant negative effect on the relationship between ownership concentration audit quality of listed oil and gas companies in Nigeria, from the coefficient of -4.135281 with z-value of -2.77 , which is statistically significant at $5 \%$ level of significance ( $p$-value of 0.006 ). This result suggests that an increase in ownership concentration is likely to affect the audit quality of financial reports of firms in the oil and gas sector. Based on this, the study rejects the null hypothesis which states that audit committee financial expertise does not significantly moderate the relationship between ownership concentration and audit quality of listed oil and gas companies in Nigeria.

\section{DISCUSSION OF FINDINGS}

Moderating Effect of Audit Committee Financial Expertise on monitoring attributes and Audit Quality.

The study tested whether audit committee financial expertise as a moderator has any significant effect on the relationship between non-executive directors and the audit quality of listed oil and gas companies in Nigeria. The study found that audit committee financial expertise significantly moderates the relationship between non-executive directors and the audit quality of listed oil and gas companies, suggesting that non-executive directors help to ensure high-quality audits, especially when the company has audit companies' members with finance and accounting expertise.

Consequently, a higher proportion of non-executive directors on boards are expected to induce a more effective monitoring function which then leads to more reliable financial reporting. This finding supports those of Olatunji and Stephen (2011), Akhidime (2015), Ibrahim and Jehu (2018), Abdulmalik (2015) who revealed that non-executive directors have a significant influence on audit quality. Suggesting that an increase in the number of non-executive directors does enhance the audit quality as predicted by the agency theory.

The moderating role of the audit committee financial expertise has a positive and significant influence on the relationship between ownership concentration and audit quality of listed oil and gas companies in Nigeria. The import of this finding is that there is a likelihood that an effective audit committee expertise will contribute to improving the influence of ownership concentration on audit quality.

The formal linkage between the board of external auditors is to typically collaborate with management in selecting the external auditor, often subject to shareholder ratification. Since the auditor is to look to the board as its client, it is reasonable to expect the board to review the overall planned audit scope and proposed audit fee.

These relationships are guided by agency theory. The finding is in line with the findings of Musa and David (2020), David, Uche, and Azah (2019) Ojeka, Fakile, Iyoha, Adegboye and Olokoyo (2019), Mohamed and Ozkhan (2010), Akhidime (2015), Khudhari, Al-Zubadi and Ali (2018), Ghafran and O'Sullivan (2017).

\section{Summary}

The operation of a good monitoring system reduces the negative effects of earnings management as well as the likelihood of creative financial reporting arising from fraud and errors. Several corporate reporting failures over the years have been attributed to the inherent weaknesses in the monitoring systems of companies. The study examined the combined effects of non-executive directors, ownership concentration and audit quality of quoted oil and gas companies in Nigeria.

The study examined issues regarding corporate monitoring and audit quality from a global perspective and in Nigeria. It highlighted the scant literature as well as an increasing level of poor governance and oversight roles, which results in poor audit quality of financial reports. To investigate the effect of monitoring attributes on audit quality, some basic research questions, research objectives, and hypotheses were raised in line with the specific variables of the study. The study spans from 2015 to 2019. The chapter also highlighted the significance of the study within the framework of various stakeholders.

The study employed a correlational research design and used data from all the ten oil and gas firms listed on the Nigerian stock exchange. The empirical review was also, done to identify the gaps the study intended to fill. The study discussed theories such as the agency theory, stewardship theory, resource dependency theory, and positive accounting and through the filtering process, nine of the companies were used for data collection. 


\section{Moderating Effect of Audit Committee Financial Expertise on Relationship between Monitoring Attributes and Audit Quality of Listed Oil and Gas Companies in Nigeria}

Finally, the result of the logistic regression which was obtained with the aid of STATA 13 was statistically described, presented, analyzed, and discussed using the software. The result of the regression analysis showed that moderating effect of audit committee financial expertise and monitoring attributes can be used to predict the audit quality of financial reports of oil and gas companies in Nigeria.

Specifically, the result showed that non-executive directors' ownership concentration has a significant effect on the audit quality of quoted oil and gas companies in Nigeria when moderated by audit committee financial expertise.

\section{CONCLUSION}

There is a significant positive association between monitoring attributes and audit quality of listed oil and gas companies in Nigeria when moderated by audit committee financial expertise.

The study has statistical evidence to conclude that ownership concentration has a strong influence on audit quality. This infers that companies with concentrated ownership have large shareholders that can affect management, especially when they become board members, and they have a lot beyond the board. These perceptions can be used to predict the audit quality of companies. Financial mastery is fundamental to guarantee that the audit committee satisfies their essential obligations of regulating the financial reporting and upgrading financial reporting quality. The Financial Expertise of the Audit Committee is essential since the committee is in charge of the auditing process and audit quality. These relationships are guided by agency theory as they are directly related to the functions of the audit office.

\section{RECOMMENDATIONS}

The study recommends that the composition of non-executive directors as members of the board should be sustained and improved upon to enhance audit quality. It also recommended that companies should increase the percentage of block holders as this may cause positive changes in an organization. This will increase the preference for big4 external auditors since strict monitoring is required by block holders who are willing to pay any cost.

\section{Contribution to Knowledge}

This research contributed to the knowledge in the study of the effects of corporate governance on the quality audit of listed oil and gas companies in Nigeria by:

1. Showing the importance of the Non-Executive Director, Ownership Concentration, and Audit Committee to the quality audit level of the listed oil and gas companies in Nigeria.

2. This opens the floor for further research in corporate governance and audit quality in the oil and gas sector to fill the gap of inadequate research work in the area.

3. immense significance for policy formulation, practice, and contribution to knowledge.

\section{Limitations of the Study}

The impact on the compensation exposed by the disparity in the percentages of ownership concentration named by one or more investors could also be an attractive problem to be addressed.

\section{Suggestion for Studies}

The new code of corporate governance addresses so many issues bothering on monitoring and governance hence, new endevours can make massive use of the new code. The study dis nit capture moderating variables as such other studies may consider variables that were not used in this study.

\section{REFERENCES}

1) Abdulmalik, S., Ahmad, A.C. \& Aliyu, U.B. (2015), "Financial reporting quality: the role of independent and grey directors, board continuous training and internal audit function", IPBJ, 7 (2), 40-57.

2) Abu ljela, I., \& Hamdan, A. (2010). "Auditing quality effect on ban earnings management: Evidence from Jordan". Arab Journal of Administrative Sciences, 17(2), 277-319.

3) Adelopo, I. A. (2010), Voluntary Disclosure Practices among Listed Firms in Nigeria Available at SSRN: http://ssrn.com/abstract.

4) Adeyemi \& Temitope (2010). Audit quality, corporate governance and firm characteristics in Nigeria, International Journal of Business and Management, 5 (5), $169-179$. 


\section{Moderating Effect of Audit Committee Financial Expertise on Relationship between Monitoring Attributes and Audit Quality of Listed Oil and Gas Companies in Nigeria}

5) Akhidime, S. (2015) Board structure, corporate characteristics and audit quality of Nigerian banks. International Journal of Economics, Commerce and Management United Kingdo $m$ 3(6) 12-31.

6) Asiriuwa, Aronmwan, Uwuigbe and Uwuigbe (2018), Assessment of the Effects of Firms" Characteristics on Earnings Management of Listed Firms in Nigeria. Asian economic and financial review 2222-6737.

7) Barney, J. (1991). Firm resources and sustained competitive advantage. Journal of Management, 17, 99-120.

8) Becker, C. L., Defond, M. L., Jiambalvo, J. \& Subramanyam, K. R. (1998). The effect of audit quality on earnings management. Contemporary Accounting Research, 15(1), 1 -24.

9) Behn, B. K., Choi, J., \& Kang, T. (2008). Audit quality and properties of analyst earnings forecasts. The Accounting Review, 83 (2), 327-349.

10) Cadbury (1992), The Financial Aspects of Corporate Governance. London: Gee \& Co. p1-90.

11) Claessens, S. \& Djankov, D., (1998), Disentangling the incentive and entrenchment effects of large shareholders. Journal of Finance. 57 (6).

12) Copley, M., (1991). Auditor tenure fixed fee contracts and the supply of substandard single audits, Public Budgeting and Finance, 13, 23-35.

13) Chambers, D., \& Payne, J. (2008). Audit quality and the accrual anomaly. SSRN Working Papers. Recuperadoem 20 dezembro, 2013,

14) David, C. M., Uwaleke, J. U. \& Aza, M. (2019) Effect of Institutional shareholding and Ownership concentration on audit quality of listed oil and gas companies. Journal of Accounting (JOA)Vol.8 Issue1

15) David, C. M., Uwaleke, J. U. \& Aza, M. (2020) Effect of Non-executive director and independent directors on audit quality of listed oil and gas companies. Journal of forensic accounting and fraud Investigation (JFAFI) VOL.5, Issue 1

16) David, C. M., \& Musa M.A. (2020) COVID-19 Pandemic and Economic Recession: Implication for Insttitutional Shareholding and Allied Matters. International journal of sustainable Development Vol.1. No.7

17) DeAngelo, L. E. (1981). Auditor size and audit quality. Journal of Accounting and Economics, 3 (3), 183 - 199.

18) Deis, D., \& Giroux, G. (2002). "Determinants of audit quality in the public sector". The Accounting Review, 67(3), 462479.

19) Enofe, E., Aronmwan, A., \& Abadua, D., (2013). Audit Quality and Accrual - Based Earnings Management of Quoted Companies in Nigeria Augustine Journal of Economics and Finance. 2321-5933, 2, (1) 07-16.

20) Fama, E.F. \& Jensen, M.C. (1983), "Separation of ownership and control", The Journal of Law and Economics, 26 (2), 301325.

21) Farber \& David. (2005). Strategic management, concepts and cases. New Jersey: Pearson Prentice hall, Inc. 10th Ed.

22) Ghosh, A., Marra, A., \& Moon, D. (2010). Corporate boards, audit committees, and earnings management: Pre- and postSOX evidence. Journal of Business Finance \& Accounting, 37, 1145-1176.

23) Gu, Z., Lee, C. W. J., \& Rosett, J. G. (2005). What determines the variability of accounting accruals? Review of Quantitative Finance and Accounting, 24 (3), 313-334.

24) Hillman T.I., \& Cannella, Y., (2000). The resource dependence role of corporate directors: Strategic adaptation of board composition in response to environmental change. Journal of Management Studies, 37, 235-255.

25) Ibrahim \& Jehu (2018). Evaluating the Relationship between Ownership Structure as Corporate Governance Mechanism and Accounting Earnings Management Tools on the Financial Performance. Journal of Emerging Trends in Economics and Management Sciences. ANYR, Vol.9

26) ICAEW (2002). Audit Fees Survey [online]. The Institute of Chartered Accountants in England and Wales [cited 13 March 2013]. Available from World Wide Web:

27) Jensen, M. C. et al., (1983). Separation of Ownership and Control. Journal of Law and Economics, 26 (2), 301-325.

28) Jensen, M., \& Meckling, W. (1976). Theory of the firm: Managerial behaviour, agency costs and ownership structure. Journal of Financial Economics, 3,305-360.

29) Johnson, J, (1996). The unofficial economy in transition, Brookings Paper on Economic Activity, 2, 159-22.

30) Kim, K., Chung, C., \& Firth, A., (2003). Auditor Conservatism and Reported Earnings. Accounting Business Research, (33), 19-32.

31) Kakabadse, K., \& Kakabadse, K., (2007). The effectiveness of non-executive directors in Chinese state-owned enterprises. Management Decision Vol. 48 No. 7, pp. 1063-1079. 


\section{Moderating Effect of Audit Committee Financial Expertise on Relationship between Monitoring Attributes and Audit Quality of Listed Oil and Gas Companies in Nigeria}

32) Kanagaretnam, K., Krishnan, G., \& Lobo, G.J. (2010). An empirical analysis of auditor independence in the banking industry. The Accounting Review, 85 (6), 2011-2046.

33) Khudhari, A. A., (2018). Female directors and earnings management: Evidence from UK companies. International Review of Financial Analysis, 39(Supplement C), 137-146.

34) Ilaboya O. J, \& Ohiokha F. I., (2013). Audit firm characteristics and audit quality in Nigeria, International Journal of Business and Economics Research. 3 (5), 187-195.

35) Mbatuegwu, D.C., Musa, M.A., Ugah, and Komolafe E.T (2021) Effect of COVID-19 on Institution a Shareholding, Independent Director, and audit committee on audit report of listed oil and gas companies in Nigeria. International Journal of Economics, Commerce and Management United Kingdom Vol. IX, Issue 1

36) Mgbame A. \& Onoyase E.R., (2015). Corporate Governance and Audit Quality in Nigeria. ESUT Journal of Accountancy, $4(1), 138-145$

37) Morrin \& Jarrell, G. (2001). Leadership structure: separating the CEO and chairman of the board. Journal of Corporate Finance, 4(3), 189-220.

38) Murtaza, S. Noor, A. Aguir, A. and Saadia Batool, S. (2020) carried a work on the role of ownership concentration and dividend policy on the firm performance of chemical sector firms of Pakistan SEISENSE Journal of Management / Accounting \& Finance Vol. 3 No.2

39) Musa M.A., \& David, C. M., (2020) Strategic Implications of Institutional Shareholding and Non-executive Directors on Audit quality of listed oil and gas companies in Nigeria. International Journal of Sustainable Development Vol.1. No.7.

40) Ndubuisi, A., \& Ezechukwu, E. (2017). Determinants of audit quality: evidence from deposit money banks listed on Nigeria stock exchange. International Journal of Academic Research in Accounting, Finance and Management Sciences 7(2) 117130.

41) Ogbechie, C \& Koufopoulos, D.N (2010). Corporate Governance and Board Practices in Nigerian Banking Industry.

42) O'Sullivan, N. (2000). The impact of board composition and ownership on audit quality: Evidence from large UK companies. British Accounting Review, 32(4), 394-414.

43) Palmrose, (1988). The circumstances and legal consequences of non-GAAP reporting: Evidence from restatements. Contemporary Accounting Research, 21(1), 139-180.

44) Penrose, E. (1959). The Theory of Growth of the Firm. New York, NY: Wiley Publication

45) Pfeffer, J., \& Salancik, G. R. (1978). The external control of organizations: A resource dependence perspective. New York: Harper and Row.

46) Piot, C. \& Janin, R. (2005). External auditors, audit committees and earnings management in France. European Accounting Review, 16(2), 429-454.

47) Romanus, R. N., Maher, J. J., \& Fleming, D. M. (2008). Auditor industry specialization, auditor changes, and accounting restatements. Accounting Horizons, 22 (4), 389-413.

48) Sanusi, (2013), "The association between internal governance mechanisms and corporate value: evidence from Bahrain", Asian Academy of Management Journal of Accounting and Finance, 8 (1), 67-92.

49) Shleifer, A. and Vishny, R.W. (1986) 'A survey of corporate governance', The Journal of Finance 52(2): 737-783.

50) Shukla, A., Narayanasamy, S., Ayyalusamy, K. and Pandya, S.K. (2020), "Influence of independent directors on the market risks of Indian banks", Journal of Asia Business Studies, Vol. ahead-of-print No. ahead-of-print. https://doi.org/10.1108/JABS-01-2020-0010

51) Teoh, S. H., \& Wong, T. J. (1993). Perceived auditor quality and the earnings response coefficient. The Accounting Review, 68 (2), 346-366.

52) Thomsen S., \& T., Pedersen. (2000). Ownership Structure and Economic Performance in the largest European Companies. The Strategic Management Journal 21: 689-705.

53) Yoon, Y.S. (2012). Is earnings management opportunistic or beneficial? An agency theory perspective. International Review of Financial Analysis, 17(3), 622-634.

54) Zagonov, M. (2011). Audit quality and bank risk under heterogeneous regulations. Proceedings of the European Accounting Association, Annual Meeting, Rome, Italy, 34.

55) Zakaria, O., (2010). A new perspective on board composition and firm performance in an emerging market", Corporate Governance, 10 (5), $647-661$. 